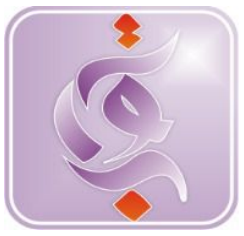

\title{
GAMBARAN PERILAKU PEMAAFAN DALAM KONFLIK PERSAHABATAN
}

Received:1 $0^{\text {th }}$ September 2019; Revised: 06 ${ }^{\text {th }}$ October 2019; Accepted: $23^{\text {th }}$ October 2019

\section{Elfi Shabrina}

UIN Imam Bonjol Padang

Email: shabrinaelfi49@,gmail.com

Dra. Hasnawati. M.Ag

UIN Imam Bonjol Padang

Email: hasnawati@uinib.ac.id

Fadhilah. S.Psi., M.Pd.I

UIN Imam Bonjol Padang

Email: Fadhilahrustam1@,gmail.com
Abstrack. Penelitian ini mengungkap Gambaran Perilaku Pemaafan dalam Konfilk Persahabatan pada dua remaja akhir. Teori pemaafan yang dipakai terdiri dari empat fase yaitu fase pengungkapan (uncovering phase), fase keputusan (decision phase), fase tindakan (work phase) dan fase pendalaman (outcome phase) (Nashori, 2008). Penelitian menggunakan metode kualitatif dengan mengumpulkan data melalui observasi dan wawancara. Subjek penelitian/informan penelitian ini adalah dua remaja akhir di Batuang Taba Kelurahan Batuang Taba Kecamatan Lubuk Begalung. Teknik sampling yang di gunakan dalam penelitian ini adalah purposive sampling karena sampel disesuaikan dengan tujuan pengambilan data penelitian. Adapun data yang digunakan dalam penelitian ini adalah teknik analisis data, koding, dan tahap Interprestasi. Hasil penelitian dapat disimpulkan gambaran proses memaafkan yang dilakukan oleh kedua remaja akhir secara keseluruhan hampir sama namun faktor pendorong untuk melakukan tindakan memaafkan kedua subjek berbeda, "M" terdorong untuk memaafkan lebih didominasi oleh faktor religiusitas yang dimilikinya serta dorongan oleh teman-teman sedangkan "I" di dorong oleh di dorong oleh motivasi dan nasehat-nasehat yang di berikan temantemanya. Kedua remaja melakukan tindakan memaafkan dalam waktu kurang lebih satu tahun. Setelah memaafkan mereka merasakan adanya perasaan positif, manfaat dan hikmah yang dapat diambilnya. Bentuk konflik dalam hubungan persahabatan ini adalah pengkhianatan kepercayaan yaitu sahabat menjalin hubungan dekat dengan orang yag dikasihi oleh sahabatnya. Sedangkan tingkatan kondisi perilaku memaafkan kedua remaja ialah pada tingkat $\mathrm{Al}$-afw sebab masih ada luka yang membekas dan masih teringat akan kejadian tersebut, walaupun kedua subjek telah membuka lembaran baru dengan teman-teman barunya.

Kata kunci : Pemaafan, Konflik, Persahabatan.

\section{PENDAHULUAN}

Manusia adalah makhluk sosial yang membutuhkan manusia lain untuk bertahan hidup di dunia ini. Kebutuhan akan interaksi dan komunikasi dengan sesama merupakan sesuatu hal yang sangat penting dalam kehidupan manusia hal tersebut menyimpulkan bahwa, manusia membutuhkan seorang manusia lain yang menurutnya nyaman berhubungan denganya sehingga 
terjadi pertemanan ataupun persabahatan karena persahabatan merupakan hubungan yang membuat dua orang atau lebih menghabiskan waktu bersama, berinteraksi dengan berbagai situasi, tidak mengikut sertakan orang lain dalam hubungan tersebut dan saling memberikan dukungan emosional. Hubungan yang paling penting di luar keluarga adalah hubungan yang di bangun dengan teman-teman yaitu hubungan persahabatan (Alentina, 2016).

Hubungan sosial yang positif seperti persahabatan berperan penting dalam pencapaian kepuasan hidup. Persahabatan merupakan wujud pengembangan hubungan sosial yang bersifat positif karena masingmasing individu memperoleh kesempatan belajar dari teman lainnya. Persahabatan telah menjadi sumber pengembangan kompetensi diri yang bermanfaat untuk persiapan dalam menjalani masa depan kehidupan. Sebab persahabatan memberikan kesempatan untuk mengembangkan potensi dan kompetensi bagi setiap individu. Persahabatan sebagai kesempatan bagi seseorang untuk dapat menjalin relasi dengan orang lain yang dianggap mendatangkan suatu manfaat bagi perkembangan hidupnya.

Melalui persahabatan, seseorang bisa belajar hal-hal positif dari orang lain. Memperoleh kesempatan untuk terus meningkatkan kompetensi diri, sehingga dapat memberi kontribusi positif bagi orang lain di masyarakat. Persahabatan dapat menyumbangkan hal hal positif bagi kepentingan masyarakat, seseorang merasa dirinya sebagai pribadi yang berharga dan bermanfaat bagi orang lain. Suatu persahabatan, seseorang merasa berharga karena dirinya memang benar-benar dibutuhkan oleh orang lain (Dariyo, 2017).

Persahabatan sering dimulai pada fase remaja, dimana salah satu tugas perkembangan pada remaja adalah mencapai hubungan yang lebih matang dengan teman sebaya. Hal ini sesuai dengan pendapat yang dikemukakan oleh Robinson bahwa ada peningkatan keterlibatan remaja dengan teman sebayanya dimana sumber dukungan emosional penting sepanjang transisi masa remaja. Hal ini berarti bahwa pada usia remaja, remaja membutuhkan orang lain, terutama teman sebaya.

Persahabatan pada remaja tidak terlepas dari aktivitas yang dilakukan bersama dengan sahabat-sahabatnya seperti pembicaraan yang mendalam, pemberian pertolongan satu sama lain, serta sejumlah kegiatan bersama yaitu makan bersama, menonton film, berbelanja dan berolahraga. Suatu penelitian, tentang remaja membuktikan bahwa remaja menghabiskan waktu rata-rata 103 menit per hari untuk interaksi yang berarti dengan sahabat dibandingkan dengan hanya 28 menit per hari dengan orang tua.

Pada remaja, yang ditekankan dalam sebuah hubungan persahabatan adalah kesetiaan mereka. Sahabat bagi remaja dianggap sebagai orang kepercayaan yang penting, yang menolong remaja melewati berbagai situasi yang menjengkelkan (seperti kesulitan dengan orang tua dan putus pada hubungan romantis) dengan menyediakan dukungan emosi, nasihat, serta memberikan informasi. Sahabat juga memberikan perlindungan bagi remaja dari kemungkinan kejahatan teman sebaya lainnya (Santrock, 2003:229-230).

Sebuah hubungan persahabatan akan ada sebuah konflik yang muncul. Konflik fenomena yang tidak dapat dihindari dalam setiap hubungan persahabatan. Menurut Deutsch konfilk dapat terjadi ketika ada ketidaklarasan dalam aktifitas-aktifitas (Prasetyaningrum \& Silfiasari, 2017). Faktor penyebab konflik berasal dari diri masingmasing individu yang dapat berupa keegoisan masing-masing ataupun ditemukan ketidakcocokan yang membuat suatu hubungan renggang, menjadikan hubungan persahabatan tidak berjalan dengan harmonismenjadikan hubungan persahabatan tidak berjalan dengan harmonis. 
Konflik yang terjadi memerlukan sebuah tindakan penyelesaian, agar permasalahan tersebut tidak menjadikan hubungan persahabatan tersebut berakhir. Tindakan yang diperlukan yaitu memaafkan. Menurut Huges memaafkan merupakan cara untuk memperbaiki harmonisasi sosial. Untuk sebagian orang memaafkan adalah suatu kebutuhan karena dapat memperbaiki hubungan yang telah rusak (Paramitasari \& Alfian, 2012). Pada suatu hubungan yang positif, ketika individu sedang berkonflik dengan orang lain, maka konflik tersebut cepat dan diselesaikan ketika salah satu mau memaafkan yang lain

Penelitian yang dilakukan Mc.Cullough dkk (dalam Prasetyaningrum \& Silfiasari, 2017) menjelaskan bahwa memaafkan dapat memulihkan hubungan sosial yang positif diantara dua orang yang sedang berkonflik, memaafkan dapat menghalangi timbulnya agresi dan kekerasan dalam konflik interpersonal. Pernyataan tersebut diperkuat dengan penelitian yang dilakukan oleh Ficham yang menyatakan bahwa pemaafan atau pengampunan memiliki potensi yang lebih besar untuk memperbaiki hubungan sosial. Dampak dari pemaafan adalah hubungan sosial yang tadinya sempat retak dan rusak dapat kembali menjadi baik, dengan memaafkan maka motivasi untuk membalas dendam akan berkurang.

Meski memaafkan dapat memperbaiki suatu hubungan yang tengah berada dalam konflik, namun tidak semua orang dapat melakukanya. Remaja yang berada pada konflik hubungan persahabatan, sering kali enggan untuk memberikan maaf meski hubungan persahabatan tersebut telah berjalan lama, apalagi hal yang menjadi pemicu konflik adalah perihal kesetiaan dan kepercayaan sebab itu lah yang paling penting dalam suatu hubungan persahabatan.

Fenomena yang terjadi pada hubungan persahabatan Remaja di Batuang Taba, Persahabatan yang mereka jalin dimulai sejak mereka berada di bangku sekolah menengah atas, kegiatan yang sering mereka lakukan bersama seperti menonton, makan bersama, jalan-jalan bersama menjadikan mereka semakin dekat setiap harinya. Kedekatan wilayah tempat tinggal membuat mereka semakin akrab setiap harinya.

Konflik terjadi pada hubungan persahabatan ini, dipicu oleh pengkhianatan kepercayaan yang dilakukan oleh sahabatnya. Yaitu sahabat tersebut menjalin hubungan dekat dengan orang yang dikasihi dan disayangi oleh sahabatnya tersebut. Perselingkuhan itu terjadi ketika mereka sama-sama berada di bangku sekolah menengah atas.

Selingkuh adalah perbuatan atau aktifitas yang tidak jujur dan menyeleweng terhadap pasangan yaitu sesuatu yang melanggar kesepatakatan atas kesetiaan suatu hubungan. Perselingkuhan mencederai makna dan kepercayaan yang terjalin pada suatu hubungan. Apalagi perselingkuhan dilakukan dengan orang terdekat yaitu sahabat. Hal tersebut bukan hanya mencederai hubungan percintaan namun juga sangat mencederai makna dan kepercayaan pada hubungan persahabatan yang selama ini telah terbangun.

Telah tersakiti dan merasa dikhianati kepercayaan oleh sahabatnya, ada orang yang mampu memberikan maaf dan tetap menjalin hubungan persahabatan tersebut. Tetap berperilaku baik kepada sahabatnya tersebut dan tidak berniat untuk melakukan pembalasan dendam. Bahkan tidak merasa terbebani oleh kesalahan sahabatnya tersebut.

\section{KAJIAN PUSTAKA \\ Pemaafan}

Menurut Michael McCullough, salah seorang pakar dalam psychology of forgiveness, pemaafan adalah berkurangnya keinginan untuk menghindari orang yang pernah menyakiti kita, dan berkurangnya keinginan untuk melukai atau membalas dendam kearah individu tersebut dan disertai meningkatnya belas kasih (compassion) dan 
keinginan untuk bertindak secara positif ke arah orang yang menyakiti (Arif, 2016:95).

McCullough dkk mengemukakan bahwa pemaafan merupakan seperangkat motivasi untuk mengubah seseorang untuk tidak membalas dendam dan meredakan dorongan untuk memelihara kebencian terhadap pihak yang menyakiti serta meningkatkan dorongan untuk konsiliasi hubungan dengan pihak yang menyakiti (McCullough \& Worthington dkk, 1997)

Enright mendefinisikan memaafkan sebagai sikap untuk mengatasi hal-hal yang negatif dan penghakiman terhadap orang yang bersalah dengan tidak menyangkal rasa sakit itu sendiri tetapi dengan rasa kasihan, iba dan cinta kepada pihak yang menyakiti dalam (Silfiasari \& Prasetyaningrum, 2017).

Nashori (2012) pemaafan diartikan sebagai kesediaan untuk meninggalkan hal-hal yang tidak menyenangkan yang bersumber dari hubungan interpersonal dengan orang lain dan menumbuh kembangkan pikiran, perasaan, dan hubungan interpersonal yang positif dengan orang lain yang melakukan pelanggaran secara tidak adil

Menurut Hughes memaafkan merupakan cara untuk memperbaiki harmoni sosial. Untuk sebagian orang memaafkan adalah suatu kebutuhan karena dapat memperbaiki hubungan dengan orang lain (Girarld \& Mullet, 1997). Beberapa penelitian Darby \& Schlenker (1982) menemukan bahwa meminta maaf sangat efektif dalam mengatasi konflik interpersonal karena permintaan maaf merupakan sebuah pernyataan tanggung jawab tidak bersyarat atas kesalahan dan sebuah komitmen untuk memperbaikinya (Paramitasari \& Alfian, 2012)

\section{Aspek-aspek Memaafkan}

Menurut McCullough memaafkan itu dapat dibagi menjadi beberapa aspek, yaitu (Widasuari \& Laksmiawati, 2018):

a) Avoidance Motivations

$\begin{array}{ccr}\begin{array}{c}\text { Penurunan } \\ \text { menghindaris }\end{array} & \text { motivasi } & \text { untuk } \\ \text { kontak pribadi dan }\end{array}$

psikologis dengan pelaku. Korban akan membuang keinginan untuk menjaga jarak dengan orang yang telah menyakitinya. Semakin menurun motivasi untuk menghindari pelaku, membuang keinginan untuk menjaga kerenggangan (jarak) dengan orang yang telah menyakitinya

\section{b) Revenge Motivations}

Penurunan motivasi untuk membalas dendam atau melihat-lihat bahaya datang kepada pelanggar. Korban akan membuang keinginanya untuk membalas perbuatan yang telah dilakukan oleh pelaku. Semakin menurun motivasi untuk membalas dendam terhadap suatu hubungan mitra, membuang keinginan untuk membalas dendam terhadap orang yang telah menyakiti.

c) Beneviolence Motivations

Peningkatan motivasi untuk berbuat kebijakan dengan pelaku walaupun subjek merasa menjadi korban, akan tetapi subjek tetap ingin tetap berbuat kebijakan kepada pelaku. Semakin termotivasi oleh niat baik dan keinginan untuk berdamai dengan pelaku meskipun pelanggaranya termasuk tindakan berbahaya, keinginan unuk berdamai atau melihat well being orang yang menyakitinya.

\section{Proses Memaafkan}

Pemberian maaf tidak serta merta langsung memaafkan begitu saja atas kesalahan yang telah diperbuat oleh orang lain kepada diri kita, tetapi ada beberapa tahapantahapan yang dilalui, yang secara disadari atau tidak disadari terjadi dalam kehidupan seharihari. Menurut Enright (dalam nashori, 2008:54) ada 4 fase dalam pemberian maaf, diantaranya adalah:

a. Fase yang pertama adalah fase pengungkapan (uncovering phase) yaitu dimana seseorang mengalami dendam atau sakit hari kepada orang lain karena sesuatu hal. 
b. Fase yang kedua adalah fase keputusan (decision phase) yaitu ketika seseorang mengambil keputusan apakah ia akan memaafkan orang yang sudah menyakitinya tersebut ataukah tidak, tetapi dalam fase ini seseorang masih belum mengambil tindakan.

c. Fase yang ketiga adalah fase tindakan (work phase) yaitu dimana seseorang sudah mengambil tindakan untuk memberi maaf kepada orang yang sudah menyakitinya.

d. Fase yang keempat adalah fase pendalaman (outcome phase) yaitu fase kebermaknaan, yaitu memaafkan dapat memberikan manfaat kepada dirinya sendiri maupun orang lain.

\section{Faktor-faktor yang Mempengaruhi Pemberian Maaf}

Menurut

McCullough

(1998)

mengemukakan ada beberapa faktor yang menyebabkan pemberian maaf, diantaranya adalah

a. Variabel kognisi sosial yang berkaitan dengan individu yang dilukai oleh penyerangan dan serangan. Variabel ini adalah faktor utama yang kuat dalam pemaafan, misalnya adalah empati afektif, penilaian tentang tanggungjawab dan kesalahan, niat yang telah dimantapkan untuk memberi maaf, dan rumination. Ketika individu disakiti oleh orang lain, maka ia akan cenderung lebih banyak memaafkan ketika individu tersebut merasa empati atau kasihan dengan orang yang telah menyakitinya.

b. Variabel yang mempunyai kedekatan yang sedang dengan pemaafan, diantaranya adalah bentuk atau sifat dari serangan itu sendiri. Ketika seseorang yang telah menyakiti kita meminta maaf, maka kita cenderung akan memaafkan orang tersebut dan timbul pemikiran dalam diri kita bahwa mungkin saja orang tersebut tidak sengaja melakukannya. c. Faktor-faktor penyebab yang hubungannya dengan pemaafan jauh dari hubungan interpersonal dimana serangan tersebut terjadi, misalnya adalah kedekatan, kepuasan dan komitmen. Jika individu yang telah disakiti mempunyai komitmen yang baik dengan orang yang menyakitinya, maka ia akan memaafkan perbuatan orang yang telah menyakitinya tersebut.

d. Variabel-variabel yang paling jauh hubungannya dengan pemaafan, yaitu ciriciri kepribadian. Maksudnya adalah tidak selalu seseorang yang mempunyai kepribadian A maka akan lebih memaafkan pihak yang telah menyakitinya ketimbang seseorang yang mempunyai kepribadian B, C, D dan lain sebagainya.

\section{Memaafkan dalam Perspektif Islam}

Kata al'afw terulang dalam al-quran sebanyak 34 kali, 7 kali dari berbicara tentang pemaafan. Hal tersebut menunjukan akhlak saling memaafkan menjadi bagian terpenting dalam kehidupan seorang Muslim. Artinya ada konsekuensi tertentu bila seorang memaafkan atau tidak memaafkan terhadap seorang yang pernah berbuat kesalahan kepadanya. Oleh karena al-'afw adalah salah satu sifat orang bertaqwa kepada allah sebagaimana alquran menjelaskan dalam QS Ali-Imran 134 ayat tersebut mendekskripsikan sikap seorang muslim yang bertaqwa akan menghadapi seorang yang melakukan kekeliruaan terhadapnya dengan tiga cara yaitu menahan amarah, memaafkan dan berbuat baik terhadap siapapun yang berbuat kesalahan kepadanya (Shihab, 1996:246)

$A l$ 'afw memiliki kedekatan makna dengan al-shafh. Kata al-shafh dalam berbagai bentuk terulang sebanyak delapan kali dalam al-quran. Kata ini pada mulanya bearti lapang. Halaman pada sebuah buku yang dinamai shafbat karena kelapangan dan keluasanya. Dari sini kata al-shafh dapat diartikan kelapangan dada Dari kata al-shafh lahirlah al-shafhat yang 
berarti halaman. Selembar kertas yang di dalamnya terdapat tulisan dari pensil yang salah, tentu seseorang dapat mengambil penghapus karet untuk menghapusnya. Seperti inilah ketika seseorang melakukan al'afw (Shihab, 1996:248)

Dari delapan kali bentuk al-shafh yang dikemukakan, empat di antaranya didahului oleh perintah memberi maaf al-'afw tetap diperlukan, karena tidak mungkin membuka lembaran baru dengan membiarkan lembar yang telah ada kesalahannya tanpa terhapus. Itu sebabnya ayat-ayat yang memerintahkan al-shafh tetapi tidak didahului oleh perintah memberi maaf, dirangkaikan dengan jamil yang berarti indah. Selain itu, al-shafh juga dirangkaikan dengan perintah menyatakan kedamaian dan keselamatan bagi semua pihak. Perbedaan al-'afw dan al-shafh

Menurut pakar bahasa al-Qur'an arRaghib al-Ashfahani, dalam mufradat-nya bahwa Al-Șhafh berada pada tingkat yang lebih tinggi daripada al-'Afw. Pada dasarnya jika ditinjau dari segi makna, hakikatnya makna kata al-'Afw mempunyai makna kunci yakni memaafkan atau memberi maaf terhadap seseorang yang telah berbuat dosa kepada orang lain

Namun al-'Afw juga mempunyai makna menutupi, bahkan terlahir makna terhapus dan juga bisa bermakna lain yaitu kelebihan, Maksudnya ialah bahwa sesuatu yang berlebih seharusnya tidak ada dan ditinggalkan, yakni dengan memberi kepada siapa yang memintanya. Sedangkan dari akar kata $\mathrm{Al}$ Shafh lahir kata șhafhat yang antara lain berarti lembaran yang terhampar dan ini memberi kesan bahwa yang melakukannya membuka lembaran baru, putih bersih, dan belum pernah dipakai, apalagi dinodai oleh sesuatu yang harus dihapus (Widiyawati,2017)

Tentunya dalam kaitan makna al 'Afw ini, diibaratkan menghapus sebuah coretan dengan alat penghapus, tentu masih terdapat sisa-sisa noda dari hasil menghapus tersebut, begitu juga dalam hal memaafkan, dalam hati seseorang setelah memaafkan orang yang menyakitinya, meskipun sudah jelas memberikan maaf, namun bekas dan bayangbayang rasa kebencian akibat perilaku jahatnya sedikit banyak masih membekas. Seseorang yang mendzalimi tentunya membuat hati orang yang didzalimi terluka oleh perilaku tersebut bahkan tidak jarang kemudian muncul rasa benci dalam hati dan ingin membalas semua perbuatan yang telah dilakukannya (Shihab, 1996:250).

Di dalam kata al- shafh terkandung makna memperlihatkan muka yang jernih, bersalaman dan memulai persahabatan dengan lembaran (suasana) baru yang tentu saja lebih hangat. Dalam hal ini munculah perbedaan kata antara kata al'afw dan Al-Shafh memaafkan berarti menghapus kesalahan orang lain. Jika kita punya selembar kertas putih lalu ternodai atau diisi suatu kesalahan, lantas kesalahan tersebut diisi dengan pensil maka anda tentu akan mengambil penghapus dan menghapusnya. Betapa pun anda menghapus bekas kesalahan tersebut. Namun tidak lagi banyak, lembaran tersebut tidak lagi sama sepenuhnya dengan lembaran baru. Malah barang kali kertas tersebut jadi kusut dan tidak lagi bersih. Dari sinilah letak perbedaan kata Shafh yang mempuyai arti lapang dada dan lembaran baru. Al-Shafh menuntut seseorang untuk membuka lembaran baru hingga sedikitpun hubungan tidak ternodai, tidak kusut dan tidak seperti halaman yang telah dihapus kesalahannya (Shihab, 2004:368)

\section{Faktor-faktor yang mempengaruhi pemaafan dalam perspektif islam}

Pemaafan dalam Islam dipengaruhi oleh satu faktor utama, yaitu factor religiusitas (semakin tinggi religiusitas, semakin tinggi potensi pemaafan). Religiusitas adalah sebagai suatu keadaan yang ada di dalam diri seorang yang mendorongnya bertingkah laku, bersikap dan bertindak sesuai ajaran agama yang dianutnya. 


\section{Konfilk}

Dalam hubungan persahabatan, tidak selalu berjalan mulus, seringkali muncul sebuah konflik. Konflik berasal dari bahasa latin, yaitu Configere yang berarti saling memukul. Secara sosiologis, konflik diartikan sebagai proses sosial antara dua orang atau lebih (bisa juga kelompok) yang salah satu pihak berusaha menyingkirkan pihak lain dengan menghancurkan atau membuatnya tidak berdaya.

\section{Faktor Penyebab Timbulnya Konflik Persahabatan}

a. Pengkhianatan

Pengkhianatan adalah penyebab pertama timbulnya konflik alasan untuk pengkhianatan bisa berbagai macam. Misalnya membongkar rahasia pribadi atau menusuk teman dari belakang. Maka pengkhianatan dapat menyebabkan konflik dalam persahabatan, bahkan bisa sampai pada keadaan persahabatan akan berakir.

b. Tidak Adanya Dukungan Yang Baik

Persahabatan adalah semua tentang cinta tanpa syarat dan dukungan dalam hidup. Jika seorang sahabat mendukungmu dalam waktu sulit dan kritis, maka kamu juga harus melakukan hal yang terhadapnya. Namun jika hal itu tidak terjadi, maka cenderung konflik akan terjadi dalam hubungan persahabatan.

c. Cemburu

Salah satu faktor penyebab timbulnya konflik adalah cemburu. Dalam persahabatan ada sifat cemburu, baik itu terhadap pencapaian atau apapun yang kamu lakukan. Kecemburuan dapat menyebakan timbulnya sebuah konflik dalan persahabatan.

d. Perdebatan

Persahabatan artinya saling menyayangi dan membahagiakan. Meskipun setiap orang punya perbedaan pendapat, pandangan terhadap suatu hal.
Perdebatan yang berkepanjagan atau berlarut-larut dapat memicu sebuah konflik (Pertiwi, 2004)

\section{Persahabatan}

Persahabatan adalah suatu hubungan pertemanan yang lebih akrab dimana yang menjadi karakteristik paling umum dari persahabatan adalah keakraban (Intimacy) dan kesamaan (Similarity).

\section{Karakteristik Persahabatan}

Menurut Davis (dalam Fauziah, 2014), persahabatan dapat ditentukan dari karakteristik-karakteristik berikut:

a) Kesenangan (enjoyment), seseorang menikmati saat bersama temannya

b) Penerimaan (acceptance), saling menerima satu sama lain yaitu seseorang tidak berusaha untuk mngubah temannya menjadi orang lain.

c) Saling membantu (mutual assistance), teman dapat berarti saling membantu dan mendukung.

d) Percaya (confiding), saling berbagi perasaan dan pengalaman satu sama lainnya.

e) Pengertian (understanding), seseorang dapat mengerti mengapa temannya berperilaku tertentu dan dapat memperhatikan apa yang sedang dirasakan temannya.

f) Kepercayaan (trust) saling percaya satu sama lain bahwa teman bertindak sesuatu untuk kepentingan kita yang

\section{Remaja}

Remaja yang dalam bahasa aslinya disebut adolescence, yang artinya "tumbuh atau tumbuh untuk mencapai kematangan". Perkembangan lebih lanjut istilah adolescence sesugguhnya memiliki arti yang luas, mencakup kematangan mental, emosional, sosial, dan fisik. Masa remaja berlangsung antara umur 12 tahun sampai dengan 21 tahun bagi wanita dan 13 tahun sampai dengan 22 tahun bagi pria. Rentang usia remaja ini 
dibagi menjadi dua bagian, yaitu usia 12/13 tahun sampai 17/18 tahun adalah remaja awal. Sedangkan usia 17/18 tahun sampai dengan 21/22 tahun adalah remaja akir (Asrori \& Ali, 2014: 9).

\section{METODE}

Jenis penelitian yang digunakan adalah penelitian kualitatif. Penelitian kualitatif adalah suatu penelitian ilmiah yang bertujuan untuk memahami suatu fenomena dalam konteks sosial secara alamiah dengan mengedepankan proses interaksi komunikasi yang mendalam antara peneliti dengan fenomena yang diteliti (Herdiansyah, 2014:9)

Model penelitian kualitatif yang digunakan dalam penelitian ini yaitu model fenomenalogi. Secara sederhana model fenomenalogi lebih memfokuskan diri pada konsep suatu fenomena tertentu dan bentuk dari studi adalah untuk melihat dan memahami arti dari suatu pengalaman individual yang berkaitan dengan fenomena tertentu. Teknik pengumpulan data Observasi anecdotal record dan wawancara. Teknik analisis data yang digunakan yaitu organisasi data, koding dan anlisis dan tahap interpertasi. Tekhnik pengujian keabsahan data menggunakan perpanjangan pengamatan, meningkatkan ketekunan, triangulasi.

\section{HASIL DAN PEMBAHASAN}

Berdasarkan hasil penelitian yang dilakukan terhadap gambaran perilaku pemaafan dalam konflik persahabatan dua remaja bersahabat, maka dibahas sebagai berikut:

\section{Gambaran proses memaafkan pada kedua remaja}

Berdasarkan hasil penelitian, Gambaran memaafkan atau proses memaafkan yang dilakukan oleh subjek $\mathrm{M}$ memang tidak terjadi begitu saja. Melalui beberapa proses atau tahapan, Pemberian maaf tidak serta merta langsung memaafkan begitu saja atas kesalahan yang telah diperbuat oleh orang lain kepada diri kita, tetapi ada beberapa tahapantahapan yang dilalui, yang secara disadari atau tidak disadari terjadi dalam kehidupan seharihari. Menurut Enright (dalam nashori, 2008:54) ada 4 fase dalam pemberian maaf, diantaranya adalah: fase pengungkapan (uncovering phase), fase keputusan (decision phase), fase tindakan (work phase) dan Fase fase pendalaman (outcome phase)

1. fase pengungkapan (uncovering phase)

Terdapat gambaran pengungkapan pada kedua subjek M dan I yaitu subjek terlebih dahulu merasakan kecewa yang teramat besar terhadap sahabatnya, hingga rasa sakit hati, namun $\mathrm{M}$ tidak dendam terhadap sahabatnya tersebut. Berbeda dengan M, I merasa dendam terhadap sahabatnya tersebut.

2. fase keputusan (decision phase)

Pada fase kedua yaitu keputusan dimana subjek $\mathrm{M}$ mulai terfikir untuk memaafkan berkisar 5 atau 6 bulan setelah kejadian tersebut. Alasan yang mendorong subjek $M$ untuk memaafkan yaitu mengingat kembali bahwa Allah SWT maha pemaaf dan mengingat kembali masa-masa persahabatnya.

Sedangkan pada subjek I, Terfikirnya untuk memberikan maaf tidak terlepas dari adanya permintaan maaf yang dilakukan pelaku kepada korban terlebih dahulu, dan juga adanya motivasi-motivasi dari orang sekitar yaitu sahabat mereka yang lain, sehingga membuat mereka terfikir untuk memaafkan.

3. fase tindakan (work phase)

Tindakan memaafkan dilakukan subjek $M$ ketika ulang tahunya saat sahabatnya mengirim pesan selamat ulang tahun dan memaafkanya. Rentang waktu yang dibutuhkan subjek untuk memaafkan secara keseluruhan adalah sekitar satu tahun. Subjek M terdorong untuk memaafkan segala sesuatu ada balasan 
dari Allah SWT serta dorongan yang paling kuat dari motivasi sahabat-sahabtnya dan perenungan pada dirinya.

Tindakan memaafkan yang dilakukan oleh subjek I berkisar sekitar 1 tahunan, saat sahabat kembali meminta maaf ,ia melakukan tindakan memaafkan didorong oleh perenungan diri sendiri, nasehat-nasehat teman serta orang tua.

4. Fase pendalaman (outcome phase)

Setelah memaafkan ada beberapa hal positif yang dirasakan oleh kedua subjek, subjek merasakan adanya perasaan tenang dan lapang.

Bukan hanya merasakan manfaat atau hal positif setelah memaafkan, subjek mendapat suatu hikmah dibalik setelah melakukan tindakan memaafkan, bahwa segala sesuau telah ditetapkan oleh Allah, dan segala ketetapanya adalah yang peling terbaik.

2. Bentuk Konflik dalam Hubungan Persahabatan kedua remaja akhir

Konflik dalam hubungan persahabatan kedua remaja, di sebabkan oleh faktor pengkhianatan.

Pengkhianatan yang terjadi dalam hubungan persahabatan ini adalah sahabatan menjalin hubungan dekat dengan orang yang di sayangi dan di kasihi oleh sahabatnya. Pada remaja yang ditekankan dalam sebuah hubungan persahabatan adalah kesetiaan mereka. Remaja percaya bahwa sahabat harus membela satu sama lain dan tidak boleh menipu atau meninggalkan satu sama lainya (Santrock, 2003:229)

3. Kondisi perilaku memaafkan yang telah dilakukan oleh kedua remaja menurut kajian sumber-sumber Islam.

derajat atau tingkatan memaafkan yang dilakukan atau dipunyai oleh kedua subjek ialah pada tingkatan al-Afw karna memaafkan yang dilakukan kedua subjek masih meninggalkan bekas luka terhadap peristiwa tersebut, mereka masih mengingat kejadian tersebut jika bertemu kembali, meskipun pada beberapa hal mereka telah membuka lembaran baru dengan sahabat lainya, namun mereka belum benar-benar meninggalkan bekas terhadap kejadian tersebut seperti lembaran baru yang telah putih bersih tanpa meninggalkan bekas luka sedikit pun.

Karena pada dasarnya jika ditinjau dari segi makna, hakikatnya makan alafw mempunyai makna kunci yakni memaafkan atau memberi maaf seorang yang telah berbuat dosa kepada orang lain. Namun al-afw juga mempunyai makna menutupi bahkan terlahir makna menghapus. (Widiyawati, 2017). Tentunya kaitan makna al-afw ini, di ibaratkan menghapus sebuah coretan dengan alat penghapus, terdapat sisa-sisa atau noda dari penghapusan tersebut, begitu juga dalam hal memaafkan orang yang menyakiti, meskipun telah jelas memaafkan namun bekas atua bayangbayang kebencian akibat perilaku jahat sedikit banyak pasti membekas. (Purbianto, 2016)

Sedangkan al-shafh setelah memberikan maaf, orang tersebut juga harus membuka lembaran baru, yakni seakan-akan hal itu tidak pernah terjadi atau melupakan semua perbuatan orang yang berperilaku jahat. Dari sini lah letak perbedaan kata shafh yang mempunyia arti lapang dan lembaran baru. Al-shafh menuntut seorang untuk membuka lembaran baru hingga sedikitpun hubungan tidak ternodai, tidak kusut, tidak seperti halaman yang tidak di hapus kesalahanya (Shihab, 2004:368)

\section{KESIMPULAN}

Berdasarkan hasil analisis penelitian dan pembahasan Gambaran Perilaku Pemaafan dalam Konflik Persahabatan (Studi Fenomenologi pada Dua Remaja Bersahabat di Kelurahan Batuang Taba Kecamatan Lubuk 
Begalung) maka sesuai dengan fokus masalah dan tujuan yang ingin diketahui, dapat disimpulkan sebagai berikut

1. Gambaran proses memaafkan pada Kedua Remaja. "M" memaafkan sekitar 1 tahun setelah kejadian tersebut, Alasan $M$ melakukan tindakan memaafkan ialah didorong oleh religiusitas yang ada pada dirinya sedangkan subjek I didorong oleh nasehat dari teman-teman terdekat. Setelah $M$ dan I memaafkan mereka merasakan adanya manfaat dan hikmah yang dapat diambilnya

2. Bentuk Konflik pada Kedua Remaja adalah Pengkhianatan kepercayaann yaitu sahabat menjalin hubungan dekat dengan orang yang dicintai dan di kasihi sahabatnya..

3. Derajat atau tingkat kondisi perilaku memaaf yang dilakukan kedua remaja yaitu pada tingkat al-afw.

\section{DAFTAR PUSTAKA}

Alentina. (2016) Memaafkan (Forgiveness) Dalam Konfilk Hubungan Persahabatan. Jurnal Ilmiah Psikologi Vol.9 No.2

Ali, M. \& Asrori, M (2014). Psikologi Remaja Perkembangan Peserta Didik. Jakarta: Bumi Aksara.

Angelia. (2011) Hubungan Antara Kualitas Persahabatan Dengan Privasi Pada Remaja Akir. Skripsi diterbitkan. Fakultas Psikologi Universitas Gunadarma.

Arifin. (2015) Psikologi Sosial. Bandung: CV Pustaka Setia.

Arif, I. S. (2016) Psikologi Positif: Pendekatan Saintifik Menuju Kebahagiaan. Jakarta: Pt Gramedia Pustaka Utama
Dariyo. (2017) Hubungan Antara Persahabatan dan Kecerdasan Emosi dengan Kepuasan Hidup Remaja. Jurnal Psikogenesis Vol.05 no.2

Desmita. (2016) Psikologi Perkembangan Pesera Didik. Bandung: Pt Remaja Rosdakarya.

Fauziah. (2014) Empati, Persahabatan dan Kecerdasan Adversitas Pada Mahasiswa Yang Sedang Skripsi. Jurnal Psikologi Undip Vol.13 No.1

Herdiansyah. (2010) Metode Penelitian Kualitatif Untuk Ilmu-ilmu Sosial. Jakarta: Salemba Humanika

Girarld M. \& Mullet,E. ( Forgiveness in Adolescent, Young, Middle Aged, and Older Adult. Journal of Adult development vol.4 no.4

Kusprayogi, Y \& Nashori, F. (2016) Kerendahan dan Pemaafan Pada Mahasiswa. Jurnal Psikologi Humaniora Psikologi Penelitian Vol.1 No.1.

McCullough, M.E., Worthington, E. L., \& Rachal, K. C. (1997). Interpersonal forgiving in close relationships. Journal of Personality and Social Psychology

(McCullough, M. E., Rachal, K. C., Sandage, S. J., Worthington Jr, E. L., Brown, S. W., \& Hight, T. L. (1998). Interpersonal forgiving in close relationships: II. Theoretical elaboration and measurement. Journal Of Personality And Social Psychology, 75(6), 1586.)

Moleong, L. (2010) Metodologi Penelitian Kualitatif. Bandung: Pt Remaja Rosdakarya. 
151 Jurnal Al-Qalb, Jilid 10, Nomor 2, Oktober 2019, hlm. 141-151

Nashori, F. (2008). Psikologi Sosial Islami. Bandung: PT Refika Aditama

Nifkhatuzzahroh (2015) Makna Al-‘afw Dan ash-shafh dalam al-quran (Studi atas penanfsiran M.Quraish Shihab Dalam Tafsir Al-Misbah). Skripsi. Fakultas Ushuluudin Universitas Islam Walisongo Semarang

Paramitasari,R \& Alfian, I. N. (2012) Hubungan Kematangan Emosi Dengan Kecenderungan Memaafkan Pada Remaja Akir. Jurnal Psikologi Perkembangan Vol 1 No.02.

Pertiwi, A.F (2004) Memaafkan orang lain : kanjian tentang tindakan memaafkan pada subjek dengan pengalaman beberapa kali memaafkan orang lain. Tesis. F.Psi. UI : Depok

Poerwandari, K.E. (2011) Pendekatan Kualitatif dalam Penelitian Psikologi. Jakarta: LPSP Psikologi UI.

Utami, D.A. (2015). Kepercayaan Interpersonal dengan Pemaafan dalam Hubungan Pertemanan. Jurnal Ilmiah Psikologi Terapan Universitas Muhammadiyah Malang, 3, (1)

Putri. (2018) Kematangan Emosi Dan Pemaafan Pada Mahasiswa Prodi Psikologi Universitas Islam Indonesia. Skripsi tidak di terbitkan. Fakultas Psikologi Dan Ilmu Sosial Budaya Universitas Islam Indonesia Yogyakarta.

Purbianto, A. B. (2016) Komsep memaafjan dalam perseptif Al-quran dan relevansinya terhadap kesehatan mental. Skripsi. Institud Agama Islam Negeri (IAIN) Jember Fakultas Usuluddin, Adab dan Humaniora.
Santrock, J.W. (2003) Adolescence Perkembangan Remaja. Jakarta: Erlangga

Shihab, M.Q. (2002) Tafsir Al-Mishbah: pesan, kesan dan keserasian AlQur'an M. Quraish Shihab. Jakarta: Lentera Hati . (2004) Menyikap Takbir Ilahi. Ciputat: Lentera Hati (1998) Wawasan Al-Quran Tafsir Mauhu'i Atas Persoalan Umat cet VIII. Bandung : Mizan

Sugiono. (2011) Metodologi Penelitian Kuantitatif, Kualitatif dan R\&D. Bandung: Alfabeta

Slamet, S \& Markam. S (2003) Pengantar Psikologi Klinis. Jakarta: Universitas Indonesia

Susanti, S \& Prasetyanigrum. (2017) Empati, Pemaafan Dalam hubungan Pertemanan Siswa Reguler Kepada Siswa Berkebutuhan Khusus (ABK) di Sekolah Inklusif. Jurnal ilmiah psikologi terapan Vol. 05 No.1

Walgito, B. (2008) Psikologi Kelompok Yogyakarta: Andi.

Widyawati, Niken (2017) Konsep Maaf Perspektif Al-quran (Studi Tafsir Tematik) Skripsi. Fakultas Ushuluddin Adab Dan Dakwah. Institud Agama Islam Negeri (IAIN) Ponogoro. 